\author{
利用者意識からみた商店街の現状並びに課題について \\ 商店街におけるバリアに関する研究 \\ CURRENT STATUS OF SHOPPING STREETS AND ISSUES TO BE RESOLVED \\ FROM THE PERSPECTIVE OF USERS CONSCIOUSNESS \\ Study of barriers at shopping streets
}

野田りさ*，川岸梅 和**

Risa NODA and Umekazu KAWAGISHI

\begin{abstract}
As shopping streets have a variety of characteristics, it would be difficult to uniformly incorporate the concept of "barrier-free" access and universal design. In order to make shopping streets (which are city center environments) into spaces that facilitate their use by anyone, it is extremely important to determine the unique characteristics of each streets from the user's perspective, and to be aware of the trends in barriers as perceived by users. This study examined four shopping streets to determine the barriers that were perceived by users, from the perspective of both building environments and city center environments to gain a basic understanding of problems and issues at shopping streets.
\end{abstract}

Keywords : User, User Consciousness, Barrier, Shopping Street, Normalization

利用者, 利用者意識, バリア, 商店街, ノーマライゼーション

\section{1. 研究の背景と目的}

近年、我が国の高齢者人口は約 3 千万人 (高齢化率 : $24.1 \% 、 2012$ 年 10 月現在）という超高齢社会を迎えていると同時に、中心市街地 の衰退が大きな問題となっている。かつて人々の賑わいで活気に溢 れていた商店街においても衰退化の情況は顕著に表れている。

「平成 21 年度商店街実態調查報告書」によると商店街の景況に ついて「繁栄している」と回答した商店街と「衰退している」と回 答した商店街が実施している事業で最も差異がある事業はバリアフ リー（以下、BF）事業と報告されており、小さな子どもから高齢者 まで誰もが安心して快適に利用できる商店街の環境づくりが今後の 商店街にとって重要であると共に、利用者が利用しづらいと感じて いる商店街の問題点や課題を把握し、改良・改善に慗げていくこと は今後の商店街の発展に寄与すると言えよう。

川内は、著書「ユニバーサル・デザインの仕組みをつくる スパ イラルアップを実現するために」1) の中で、ユニバーサルデザイン の考え方について障がい者や高齢者等ハンディキャップを抱える人 の問題（特別な人の為の特別な問題）と捉えられがちであることを 指摘すると共に、既存のものに対する利用者の参画と継続的な改善 の必要性を述べている。既存の商店街においても、誰もが安心して 快適に過ごせるユニバーサルデザイン（以下、UD）に基づいた環境 ら゙くりを実践する為には、利用者並びに運営者の参加と協同・協働 による方策の検討が必要である。そこで本研究では、研究の前段と
して、利用者が意識する商店街の問題点や課題を明らかにすること を目的とし、全世代を対象とした利用者が商店街を構成している施 設注 1)（建物空間）並びに商店街（外部空間）を利用する際に意識す るバリア注 2)について調查し、整理・報告する。加えて、利用目的 の側面から利用者が意識するバリアの傾向について明らかにし、比 較を通じて、利用しづらいと感じている商店街の問題点や課題に関 寸る基礎的知見を得ると共に、商店街で取り組むことが可能な方策 について考察することを目的としている。

\section{2. 既往研究と本研究の特徵}

本研究に関連する既往研究について、商店街における利用者実態 の側面からは、消費者の購買地選択過程の中で消費者購買行動の特 性を明らかにした研究 ${ }^{22}{ }^{3)}$ 、購買交通手段の観点から消費者購買行 動や購買行動変化のモデル化シミュレートを行った研究 ${ }^{4)}{ }^{5)}$ 、都心 商店街の利用者特性を利用者属性や来街目的等を明らかにした研究 6)、通行量の経年的変動実態に関する研究 ${ }^{7)}$ 、商店街の座りスペー ス利用の実態や休㮩スペースの実態について明らかにした研究 ${ }^{889)}$ 、 来訪者の回遊行動と施設種構成を経年変化の側面から考察した研究 10)、祭事における商店街来街者の座り空間に関する研究 ${ }^{11)}$ 等が行わ れている。また BF やUDに通じる既往の研究は数多く、その中でも 商店街を対象とした研究では、小売店舗から商店街や商業地区にお いて BF を促進する方策について検討した研究 ${ }^{12)}$ 、高齢者の商店街
*日本大学大学院生産工学研究科建築工学専攻 博士後期課程・修士 (工学)

** 日本大学生産工学部創生デザイン学科 日本大学大学院生産工学研究科建築工学専攻 教授・博士 (工学)
Graduate Student, Dr. Course, Department of Architecture and Architectural Engineering, Graduate School of Industrial Technology, Nihon Univ., M. Eng.

Prof., Department of Conceptual Design, College of Industrial Technology, Department of Architecture and Architectural Engineering, Graduate School of Industrial Technology, Nihon Univ., Dr. Eng. 
利用実態について明らかにした研究 ${ }^{13)}{ }^{14)}$ 、商店街における車い寸使 用者への配慮の実態に関する研究 ${ }^{15)}{ }^{16)}$ 、高齢者や車い寸使用者を対 象とし、商店街の問題点を明らかにした研究 ${ }^{17)}$ 、商店街の課題に対 する利用者 (高齢者) と商店主の意識について考察した研究 18) 19) 等が行われている。

しかし、商店街において全世代を対象とした利用者が意識するバ リアに視座を置き、利用目的の側面から商店街の問題点や課題を報 告し、さらに商店街で取り組むことが可能な方策について考察した 例はなく、本研究の独自性もここにあると考える。

\section{3. 研究の方法}

本研究は、4 タイプの商店街において全世代の利用者を対象とし、 施設（建物空間）及び商店街（外部空間）の両面から利用者が意識 するバリアに視座を置き、調查・報告する。各商店街における問題 点及び課題について明らかにする上で、調查手順も踏まえた研究の 流れを以下に示す。(1)調查対象商店街の成り立ち、施設概要、街区 状況等、文献及び目視・実測調查を実施する。(2)利用者属性に関連 する事項（利用目的等を含む）、施設（建物空間）及び商店街（外部 空間）で意識するバリアについて利用者に対する聞き取り調查を実 施する。(3)利用者が意識するバリアを 4 分類別に整理し、それぞれ のバリアに対する検証を行う。加えて、利用目的別に各商店街の利 用者が意識する問題点や課題について考察する。

尚、調査対象とする 4 タイプの商店街に関して、「平成 21 年度商 店街実態調查報告書」で定義されている(1)近隣型商店街（最寄品中 心の商店街で地元主婦が日用品を徒歩又は自転車などにより買物を 行う商店街)、(2)地域型商店街 (最寄品及び買回り品が混在する商店 街で近隣型商店街よりもやや広い範囲であることから、徒歩、自転 車、バス等で来街する商店街)、(3)広域型商店街（百貨店、量販店を 含む大型店があり、最寄品より買回り品が多い商店街)、(4)超広域型 商店街（百貨店、量販店を含む大型店があり、有名専門店、高級専 門店を中心に構成され、遠距離から来街する商店街）の条件に該当 する 4 つの関東圈の商店街の事例を取り上げ、調查・分析を行う。

\section{4. 調査の概要}

\section{1 調查方法注 3)}

\section{1.1 目視 $\cdot$ 実測調査}

各商店街において商店街を構成している施設業種や建物デザイン 等に加え、問題䇢所について、現地による目視・実測調查を行った。

\subsection{2 利用者に対する聞き取り調査（表 $1 \cdot 2 \cdot 3)$}

調查は $10 ： 00 \sim 18: 00$ の間に、各商店街内を往来する利用者に対 し、直接聞き取る方法で実施した。調查対象者は利用者が意識する バリアを見出す為の調査として、全世代の通行者に対し、利用者属 性に関する事項（含利用目的）や、施設（建物空間）及び商店街（外 部空間）利用で不都合又は使いら゙らさを感じる箇所の有無（バリア の有無）を聞き、有ると回答した対象者に事前に用意したバリア項 目注 4) の中で、具体的に意識するバリアに関する聞き取りを実施注5) した。その際、自由な意見として「その他」の項目を設け、商店街 ごとに異なる意見の確認を行った。尚、調查対象者数を表 2 に示し、 表 2 に含まれるハンディキャップを抱える人の内訳を表 3 に示す。
表 1 利用者に対する聞き取り調查概要

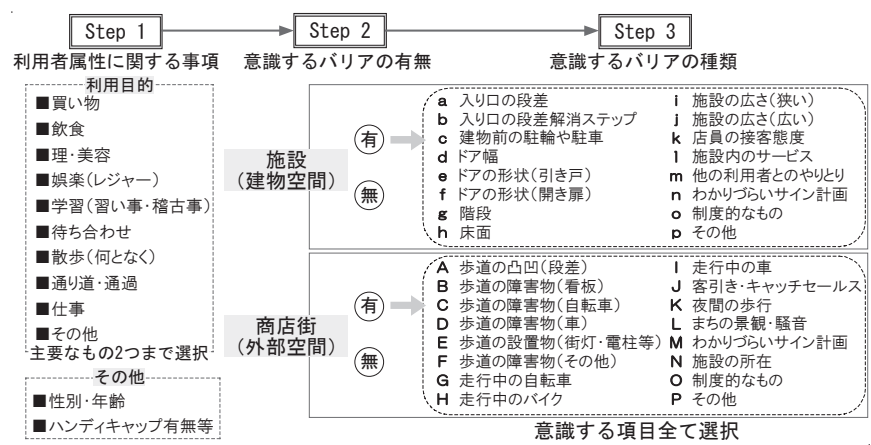

表 2 調査対象者概要 (全体)

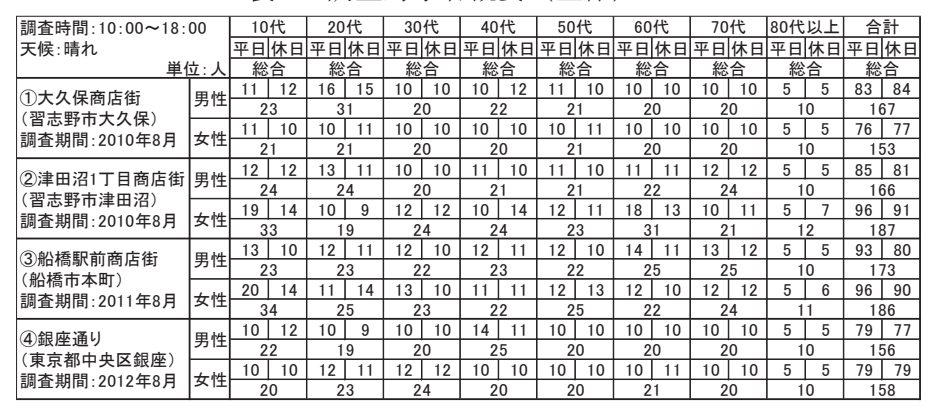

表 3 調查対象者概要（ハンディキャップを抱える人の内訳）

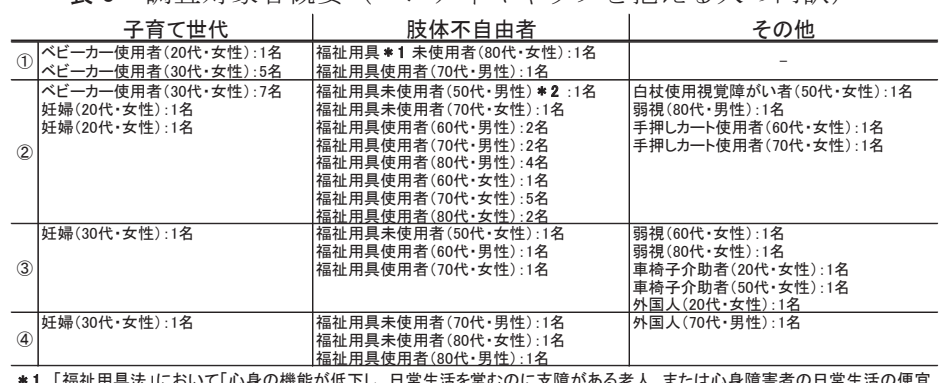

*1「福祉用具法」において「心身の機能が低下し、日常生活を営むのに支障がある老人、または心身障害者の日常生活の便宜 を図るための用具及びこれらの禣助杖」を使用している。

*2 過去に車椅子使用の経験があり、現在は福祉用具を使用していないが、歩行が不自由である。

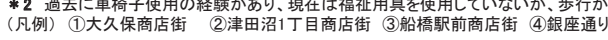

\section{2 調査対象地区（表 4 -5、図 1)}

調查対象の商店街は以下の通りである。また目視・実測調查によ る各商店街の概要（施設の業種割合注6) 等）を表 4 ・5、図 1 に示寸。

1 ) 大久保商店街 : 千葉県習志野市大久保 $1 \cdot 3$ 丁目地区注 7$)$

習志野市大久保 $1 \cdot 3$ 丁目地区は大学や高校等の文教施設を有して いる。大久保商店街は京成大久保駅と日本大学の間に位置し、通学・ 通勤者や近隣居住者が行き交う近隣型商店街である。業種に関して、 日用品等の最寄品を扱う「販売施設・店舗」が最も多く、次いで「飲 食施設」が多い構成になっている。メイン通りは許可車以外 15 時〜 18 時の間、通行不可且つ一方通行の時間式步車併用道路である。

2 ) 津田沼 1 丁目商店街 : 千葉県習志野市津田沼 1 丁目地区 注 7$)$

習志野市津田沼 1 丁目地区は、習志野市の立関と位置付けられる JR 津田沼駅等を有しており、近年は「習志野市交通バリアフリー基 本構想」事業に伴い、駅のペデストリアンデッキと地上を結ぶエレ ベーター（以下、EV）の設置等の事業が行われている。3 つの通り で構成された商店街だが、ぶらり東通り（メイン通り）に客は集中 寸る傾向があり、業種に関して、「飲食施設」が最も多く、次いで多 い「販売施設・店舗」には量販店（イオン等）を含み、最寄品の他 に買回り品を扱う地域型商店街である。ぶらり東通りは面的步車分 離道路であり、通り沿いは 5、6 層程度のビルが建ち並ぶ。 
3 ）船橋駅前商店街: 千葉県船橋市本町 $1 \cdot 4$ 丁目地区注 7$)$

船橋市本町 $1 \cdot 4$ 丁目地区は JR 船橋駅・京成船橋駅や百貨店（西 武百貨店）、大型量販店（船橋 LOFT）を有しており、「交通バリアフ リー法に基づく船橋市移動円滑化基本構想」において重点整備地区 に指定されている。また、業種に関して、「飲食施設」が最も多い広 域型商店街である。メイン通りは完全な面的步車分離道路であり、 歩道沿いに船橋市の駐輪場が設置されている。

表 4 商店街の施設業種割合

\begin{tabular}{|c|c|c|c|c|c|c|c|c|}
\hline & \multicolumn{2}{|c|}{ (1)大久保商店街 } & \multicolumn{2}{|c|}{ (2)津田沼 1 丁目商店街 } & \multicolumn{2}{|c|}{ (3)船橋駅前商店街 } & \multicolumn{2}{|c|}{ (4)銀座通り } \\
\hline & 施設数 & $\%$ & 施設数 & $\%$ & 施設数 & $\%$ & 施設数 & $\%$ \\
\hline 製造業施設 & 1 & $0.4 \%$ & & & & & 1 & $0.1 \%$ \\
\hline 事務所・オフィス & & & 6 & $4.5 \%$ & & & 275 & $32.4 \%$ \\
\hline 金融業施設 & 2 & $0.8 \%$ & 4 & $3.0 \%$ & 11 & $9.2 \%$ & 15 & $1.8 \%$ \\
\hline 販売施設·店舗(含百貨店等) & 95 & $40.3 \%$ & 25 & $18.8 \%$ & 33 & $27.5 \%$ & 179 & $21.1 \%$ \\
\hline その他の商業·業務施設 & 37 & $15.7 \%$ & 21 & $15.8 \%$ & 9 & $7.5 \%$ & 84 & $9.9 \%$ \\
\hline 病院 & 9 & $3.8 \%$ & 17 & $12.8 \%$ & 5 & $4.2 \%$ & 39 & $4.6 \%$ \\
\hline その他の医療施設 & 3 & $1.3 \%$ & 5 & $3.8 \%$ & & & & \\
\hline 飲食施設 & 63 & $26.7 \%$ & 38 & $28.6 \%$ & 45 & $37.5 \%$ & 199 & $23.4 \%$ \\
\hline 娛楽施設 & 13 & 5.5 & 9 & $6.8 \%$ & 16 & $13.3 \%$ & 44 & $5.2 \%$ \\
\hline スポーツ施設 & 3 & 1.3 & 1 & 0.8 & & & & \\
\hline その他の教育·科学・情報施設 & 9 & $3.8 \%$ & 7 & $5.3 \%$ & 1 & $0.8 \%$ & 13 & $1.5 \%$ \\
\hline 通信施設 (郵便局等) & & & & & & & 1 & $0.1 \%$ \\
\hline 休䡯·作業施設 & 1 & $0.4 \%$ & & & & & & \\
\hline 合計 & 236 & $100 \%$ & 133 & $100 \%$ & 120 & $100 \%$ & 850 & $100 \%$ \\
\hline
\end{tabular}

4）銀座通り：東京都中央区銀座 1 8 丁目地区 注7)

東京都中央区銀座 1 8 丁目地区は東京メ卜口銀座駅、百貨店（松 坂屋・三越等）や様々な有名ブランド等の高級専門店を多数有して おり、世界的にも有名な超広域型商店街である。業種に関して、「事 務施設・オフィス」、「飲食施設」の順で多く、面的步車分離道路で あるが土日祝日の午後 (12 時-18 時) は歩行者天国を実施している。

表 5 商店街の概要

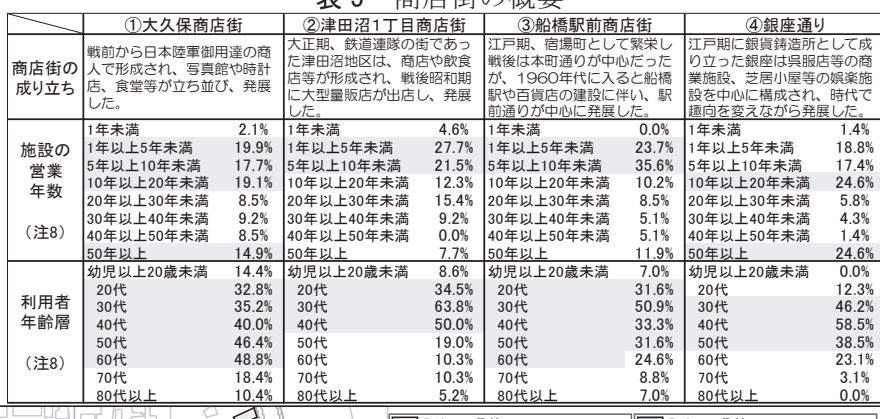

\section{inth}

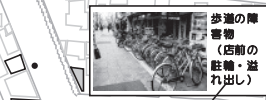

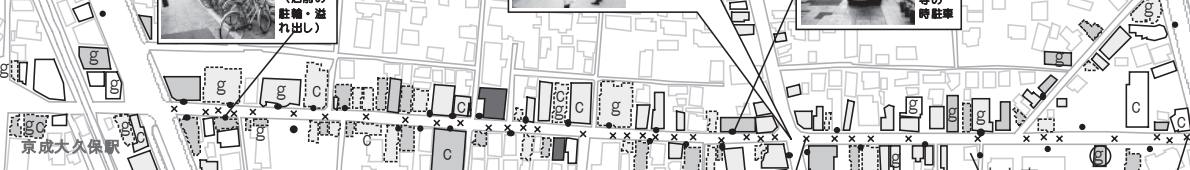

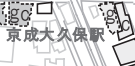

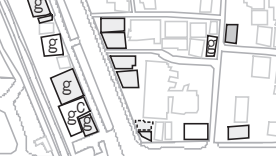

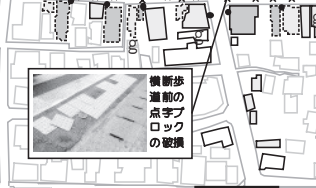

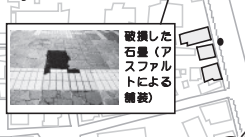

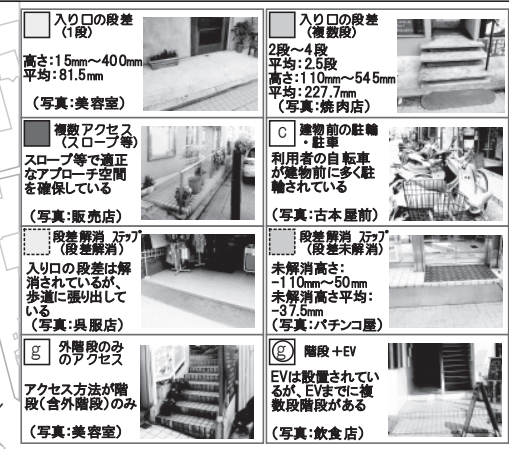

震

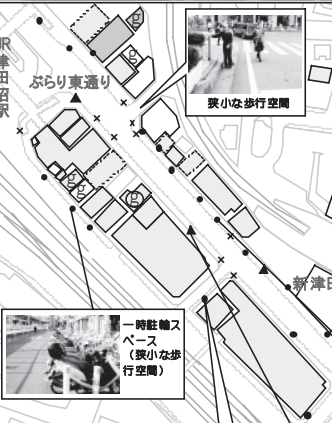

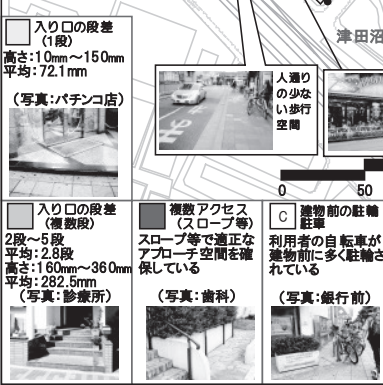

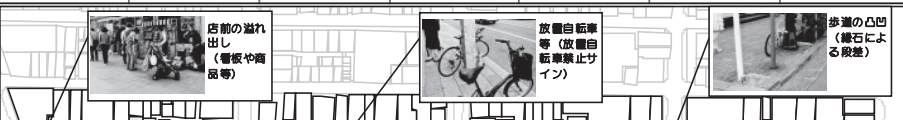

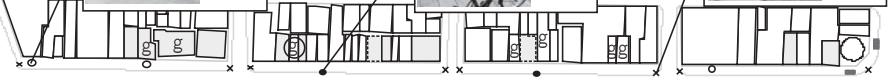

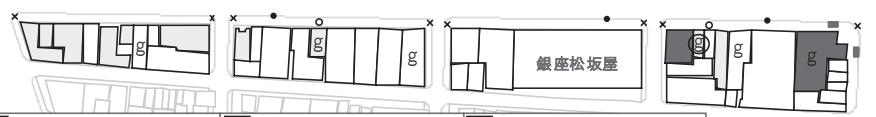

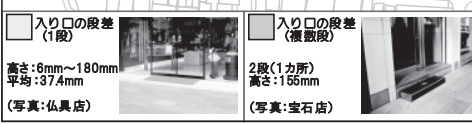

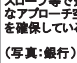

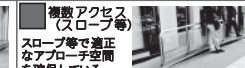

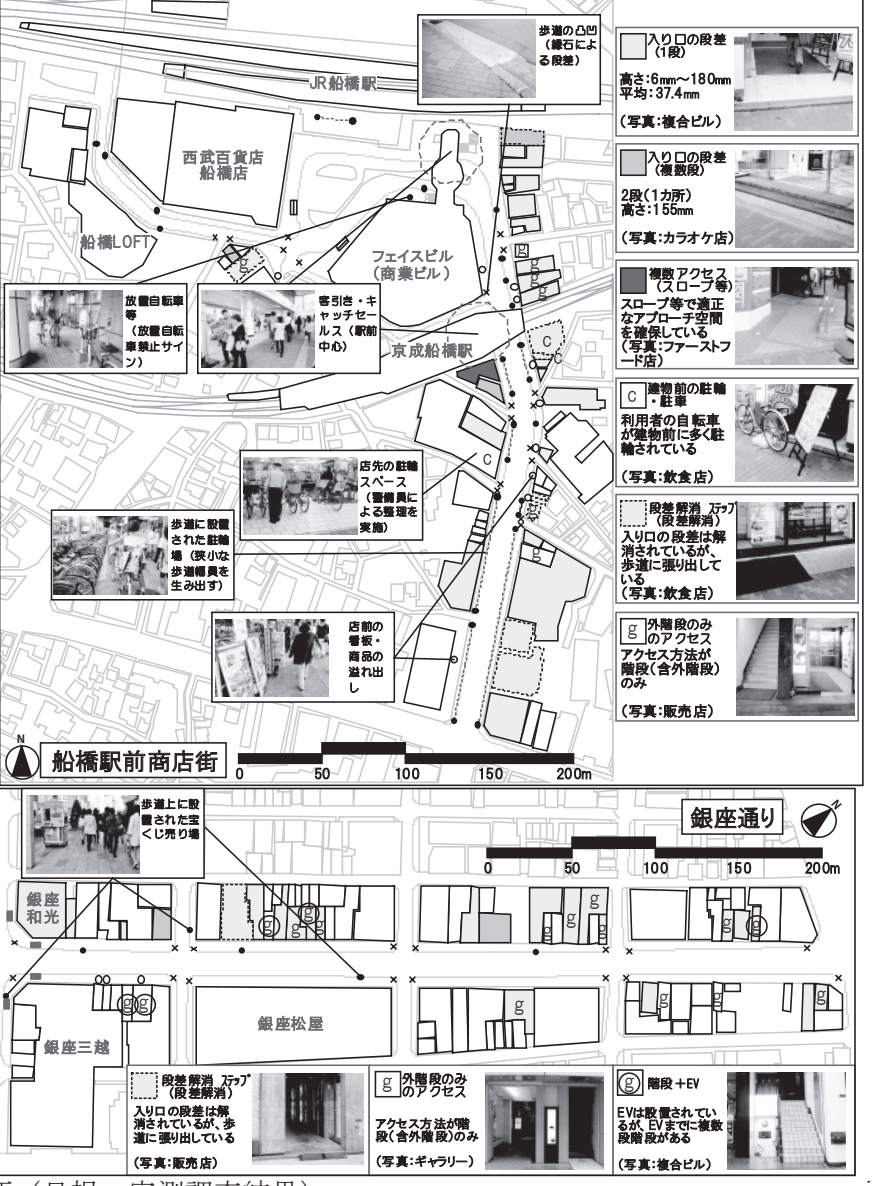

(1) 船橋駅前商店街 
5. 利用者が意識するバリアについて

\section{1 施設利用において意識するバリア（図 2・3、表 6・7)}

利用者が施設（建物空間）利用で意識するバリアに関して、大久 保商店街は $29.8 \%$ 、津田沼 1 丁目商店街は $46.0 \%$ 、船橋駅前商店街 は $21.4 \%$ 、銀座通りは $26.9 \%$ が意識するという結果を得た。また、 世代別にみると、大久保商店街、銀座通りでは 60 代が全体平均より 意識する傾向が強いが、その他の商店街においては 60 代以上の高齢 層が全体平均もしくは全体平均以下である傾向がみられる。

具体的には、全ての商店街において、物理的なバリアである「入 り口の段差」が共通して最も高い割合を占めており、次いで、大久 保商店街は「建物前の駐輪や駐車」が $23.2 \%$ 、津田沼 1 丁目商店街 は最も高い割合を占める「入り口の段差」の割合と近い「階段」が $39.3 \%$ 、船橋駅前商店街は「施設の広さ（狭い）」が $24.7 \%$ 、銀座 通りは「階段」が $29.8 \%$ で高い割合を占めている。また、男女別に 比較すると、大久保商店街では男性は「階段」が高い割合を占めて いるのに対し、女性は「建物前の駐輪や駐車」「店員の接客態度」 が高い割合を示しており、船橋駅前商店街では男性は「入り口の段 差解消ステップ」が高い割合を占めているのに対し、女性は「施設

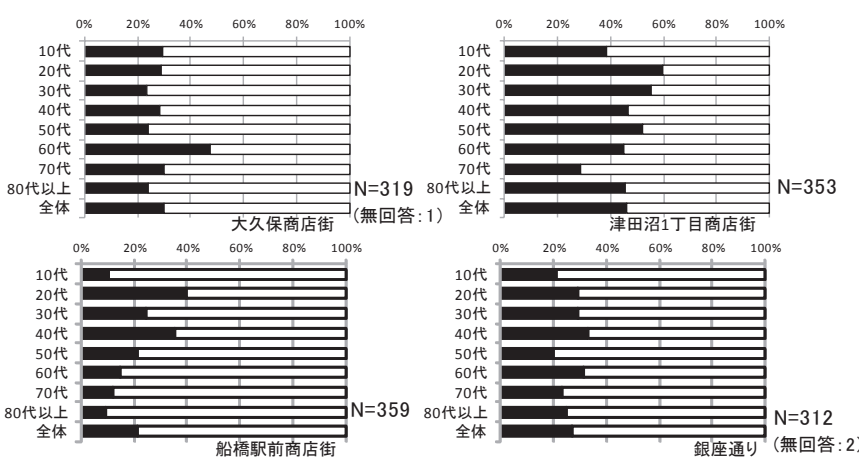

図 2 施設（建物空間）で意識するバリアの有無（年代別）

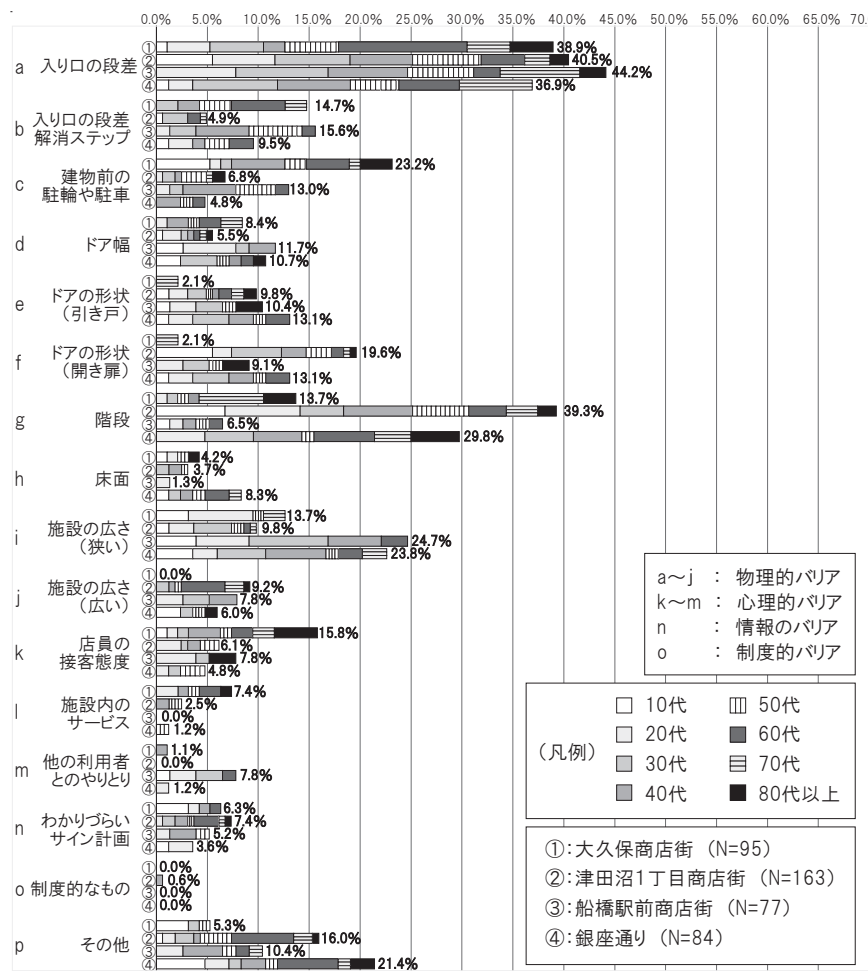

図 3 施設 (建物空間) で意識するバリアの種類（年代別・複数回答）
の広さ（狭い）」が高い割合を占める等、意識するバリアの割合順に 多少の差異がみられるが、「入り口の段差」に関しては男女共通して バリアとして意識する傾向がみられた。特に、「入り口の段差」と回 答した利用者の年齢についてみると、大久保商店街では 60 代以上の 高齢層、津田沼 1 丁目商店街では 20 代 30 代や 40 代 50 代の中年層、 船橋駅前商店街では 20 代 30 代、中年層に加えて 70 代以上の高齢層、 銀座通りでは 30 代や中高齢層の回答が多かったが、いずれも全ての 世代で回答があり、表 7 より子育て世代、肢体不自由者（杖使用者） や車い寸連れにおいても意識する傾向がみられた。以上のことから、 商店街の規模や性別、年齢、問題箇所数や段差高さに関わりなく、 利用者が施設の「入り口の段差」をバリアとして意識する傾向が顕 在していると言えよう。一方で、目視・実測調査結果より、大久保 商店街で回答が多かった「建物前の駐輪や駐車」の箇所数は大久保 商店街が最も多く、利用者意識と相関性があると言えよう。さらに、 津田沼 1 丁目商店街、銀座通りで回答が多かった「階段」に関して、 外階段のみの施設アクセスや $\mathrm{EV}$ に至るまでのアクセスにおいて数 段の階段があるビルが点在していることが要因と考えられる。

表 6 施設（建物空間）で意識するバリア（男女別・複数回答

\begin{tabular}{|c|c|c|c|c|c|c|c|c|c|}
\hline 店㢈街 & $\begin{array}{ll}\text { 性别 } \\
\end{array}$ & 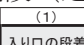 & $\operatorname{sen} x$ & 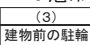 & \begin{tabular}{|l|} 
(4) \\
施設の広さ
\end{tabular} & 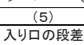 & (6) & 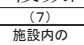 & (8) \\
\hline \multirow[b]{2}{*}{ 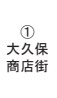 } & $\begin{array}{l}\text { 男珄 } \\
N=4 \mid\end{array}$ & 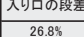 & & 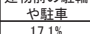 & & 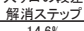 & 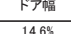 & 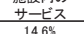 & \\
\hline & 女性 & 入乡ロの段差 & 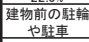 & 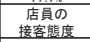 & 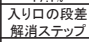 & 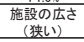 & & & \\
\hline \multirow{4}{*}{$\begin{array}{l}\text { 津涩 } \\
\text { 商店倠 }\end{array}$} & $\begin{array}{l}N \text { 算性 } \\
\end{array}$ & 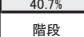 & 人吅の段差 & 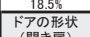 & 战下幅 & 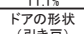 & 施設の広さ & & \\
\hline & $N=76$ & $43.4 \%$ & $32.9 \%$ & & & & 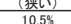 & & \\
\hline & 女性 & 入肃の段差 & 跓段 & 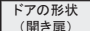 & 施設の広さ & & & & \\
\hline & & $47.1 \%$ & 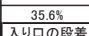 & & 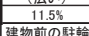 & & & & \\
\hline \multirow{2}{*}{ 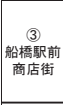 } & 男性 & \begin{tabular}{|l|} 
入у口口の段差 \\
4678
\end{tabular} & 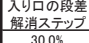 & F幅 & 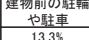 & 階孯 & 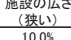 & 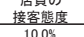 & 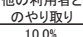 \\
\hline & 女性 & 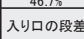 & 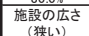 & 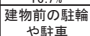 & 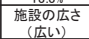 & 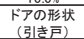 & 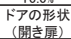 & & \\
\hline \multirow{4}{*}{ 銀座通り } & 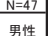 & 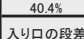 & $34.0 \%$ & \begin{tabular}{|l|}
$12.8 \%$ \\
拉設の㧁さ
\end{tabular} & & & & & \\
\hline & $N=39$ & $28.28 \mathrm{x}$ & & & & & & & \\
\hline & 女性 & 入у口口の段差 & 䘯段 & 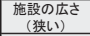 & 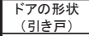 & 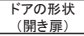 & F"ア幅 & & \\
\hline & $\mathrm{N}=45$ & $42.2 \mathrm{~s}$ & & & & & 73 & & \\
\hline
\end{tabular}

表7 施設 (建物空間) で意識するバリア (ハンディキャップを抱える利用者別)

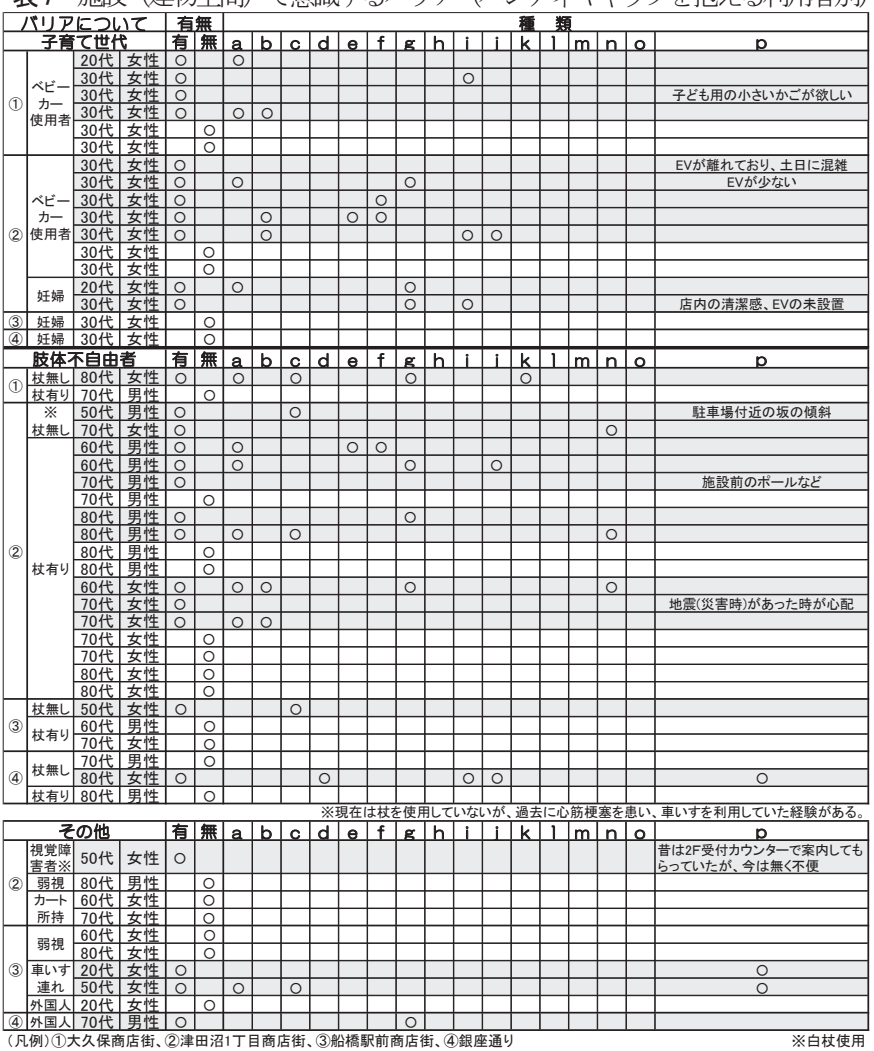


5.2 商店街 (外部空間) 利用において意識するバリア (図 4・5、表 8・9)

利用者が商店街 (外部空間) 利用で意識するバリアに関して、大 久保商店街は $80.3 \%$ 、津田沼 1 丁目商店街は $79.3 \%$ 、船橋駅前商店 街は $55.2 \%$ 、銀座通りは $35.4 \%$ が意識するという結果を得た。大久 保商店街、津田沼 1 丁目商店街、船橋駅前商店街、銀座通りの順で 意識するバリア有無の割合が低い傾向が見られると共に、全ての商 店街において商店街（外部空間）で意識するバリアの割合の方が施 設 (建物空間) 利用で意識するバリアよりも高い割合を占める傾向 がみられる。年代別の意識するバリア有無に関しても、全体と比較 して、各年代における大きな偏りはない。

具体的に、大久保商店街は「走行中の車」が $71.6 \%$ 、津田沼 1 丁 目商店街及び銀座通りは「歩道の凸凹（段差）」がそれぞれ $50.7 \%$ と $61.3 \%$ 、船橋駅前商店街は「歩道の障害物（自転車）」が $50.5 \%$ で最も高い割合を占めている。メイン通りが歩車併用道路である大 久保商店街において、静的な物理的バリアである「歩道の凸凹（段 差)」に関して、子育て世代は意識するバリアとして挙げているが、 年代別では他の商店街（メイン通りが面的に歩車分離されている） と比較して低い割合を示しており、走行中の自転車・バイク・車と
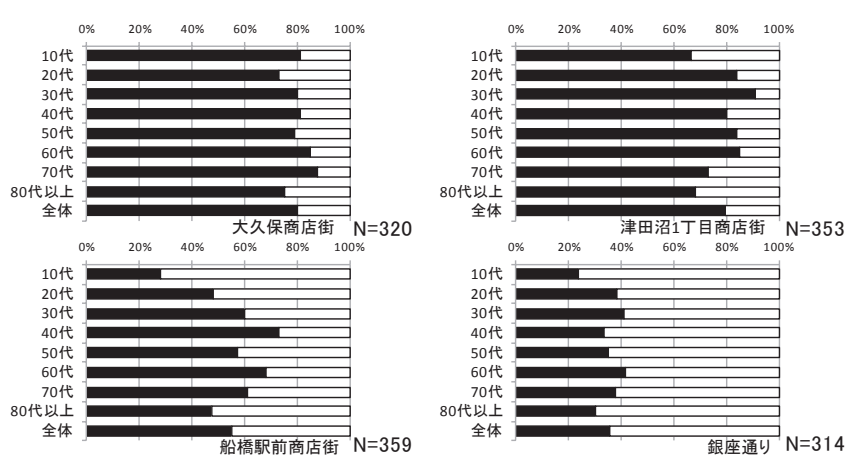

図 4 商店街（外部空間）で意識するバリアの有無（年代別）

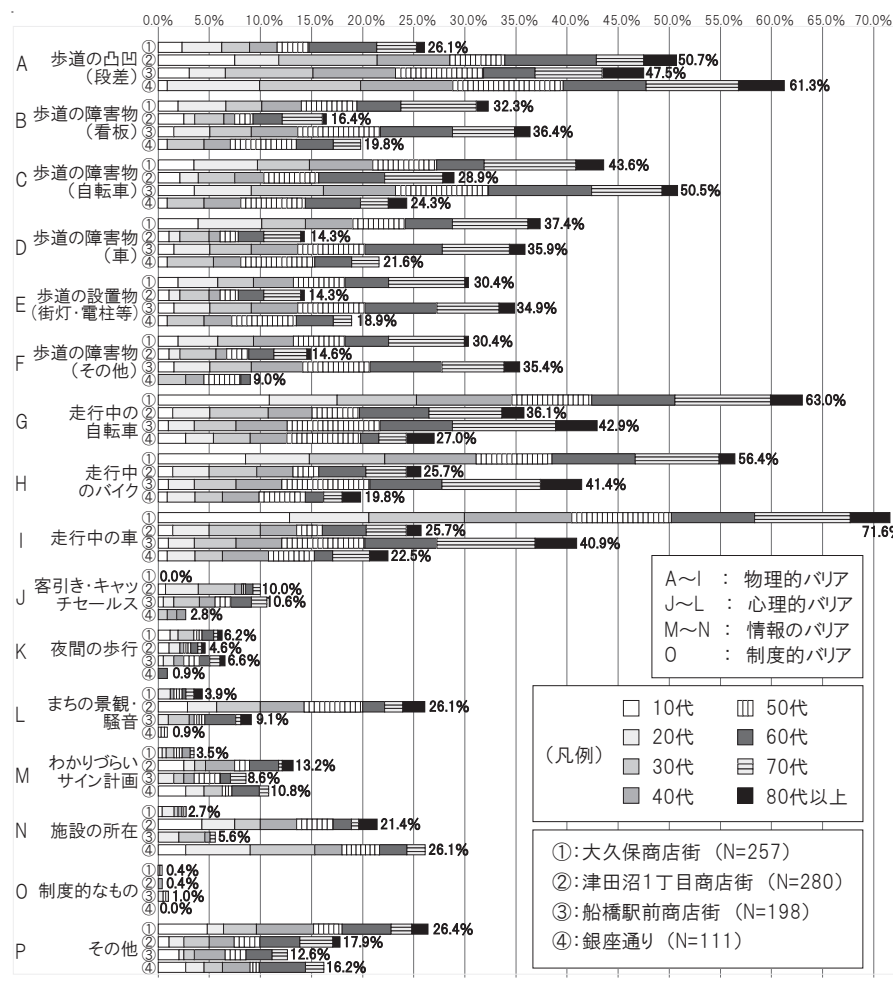

図 5 商店街 (外部空間) で意識するバリアの種類 (年代別・複数回答)
いった動的な物理的バリアについて意識する傾向が強い。

また、「歩道の障害物（自転車）」に関して、船橋駅前商店街の各 年代の割合が高い傾向がある。これは歩道に設置されている駐輪ス ペースにより人が通る有効幅が狭くなっていることが一因であると 推察され、津田沼 1 丁目商店街の肢体不自由者（杖使用者）は「歩 道の障害物 (自転車等)」を意識する傾向があることから、歩道に設 置する、より良い駐輪スペースのあり方に課題があると言えよう。

加えて、男女別に比較すると、商店街（外部空間）で意識するバ リアで高い割合を占める項目に関しては、男女で大きな差はみられ ず、大久保商店街及び船橋駅前商店街においては全ての項目で男女 共に同様のものを意識するバリアとして位置付ける結果を得た。年 代別にみても、各商店街全ての世代で商店街（外部空間）において バリアを意識すると回答があり、僅かな差異はあるものの年齢層に よる偏り傾向（高齢層に集中する等）はみられず、年齢に関わりな く利用者が商店街（外部空間）において、特に歩道における物理的 バリアについて意識する傾向が顕在していると言えよう。

表 8 商店街（外部空間）で意識するバリア（男女別・複数回答）

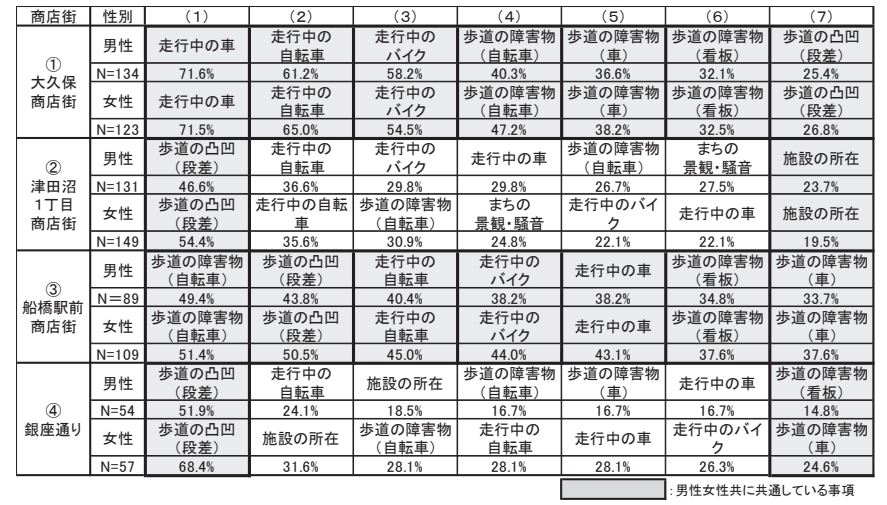
表9 商占街 (外部空間) で意識するバリア (ハンディキャップを抱える利用者別)

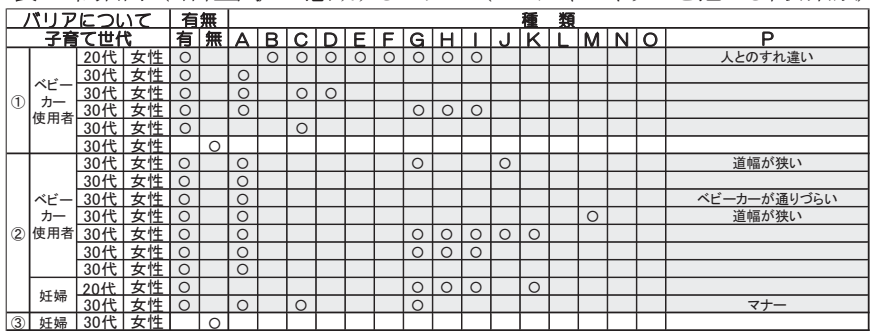

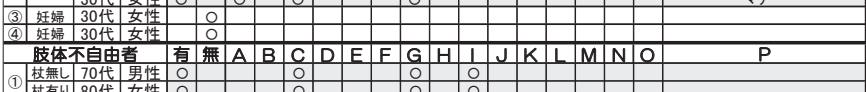

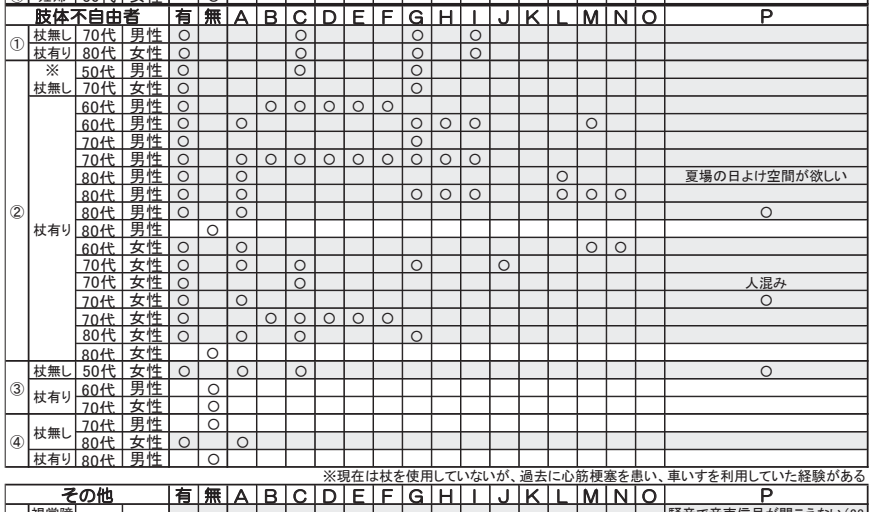

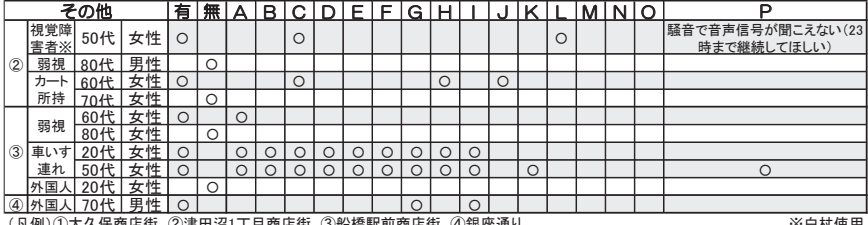




\section{3 利用目的別にみる利用者が意識するバリア}

\section{3.1 調査対象利用者の商店街利用目的（図 6)}

利用者の商店街利用目的に関して、全ての商店街で「買い物」が 最も高い割合を占める一方で、大久保商店街では「通り道・通過」 目的の利用がその他の商店街と比較して高い割合を占め、船橋駅前 商店街以外の商店街では「飲食」目的の利用、船橋駅前商店街や銀 座通りでは「仕事」目的の利用が高い割合を占める傾向がある。

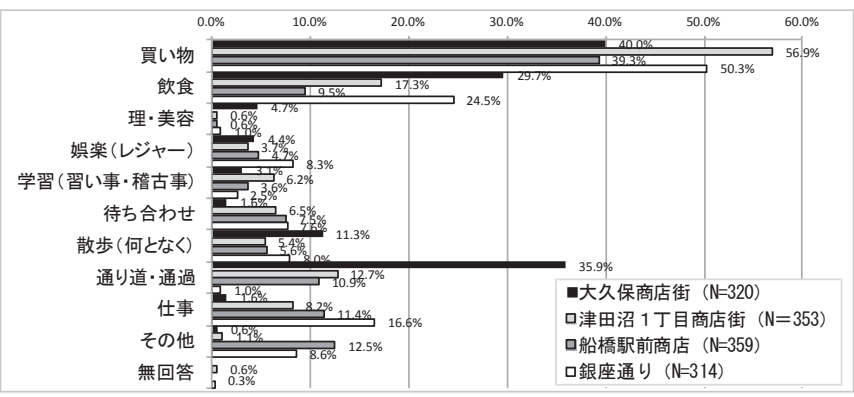

図 6 利用者の利用目的について (複数回答)

5. 3. 2 施設利用において意識するバリア（利用目的別）注9) (図 7)

利用者が施設利用で意識するバリアに関して利用目的別にみると、 大久保商店街では「娛楽（レジャー）」目的の利用者が意識するバリ アが有ると最も多く回答し、津田沼 1 丁目商店街では「飲食」、「待 ち合わせ」や「買い物」目的において意識するバリアが有ると回答 した利用者が約半数から半数以上と利用目的別に分散傾向がみられ た。船橋駅前商店街及び銀座通りにおいては全ての利用目的におい て約 2〜3 割が意識するバリアが有ると回答し、目的別に集中する傾 向はみられなかった。具体的に、各商店街の利用者が意識するバリ アについて利用目的として回答の少なかった「理・美容」や施設利 用に直接関わりない「散歩（何となく）」及び「通り道・通過」を除 く全ての項目について以下に整理する。

1 ) 買い物

「買い物」に関して、大久保商店街は $26.6 \%$ 、津田沼 1 丁目商店 街は $47.8 \%$ 、船橋駅前商店街は $25.5 \%$ 、銀座通りは $29.1 \%$ が意識 するバリアが有ると回答した。具体的には全ての商店街で「入り口 の段差」が最も高い割合を占める。また、津田沼 1 丁目商店街及び 銀座通りでは「階段」、船橋駅前商店街及び銀座通りでは「施設の広

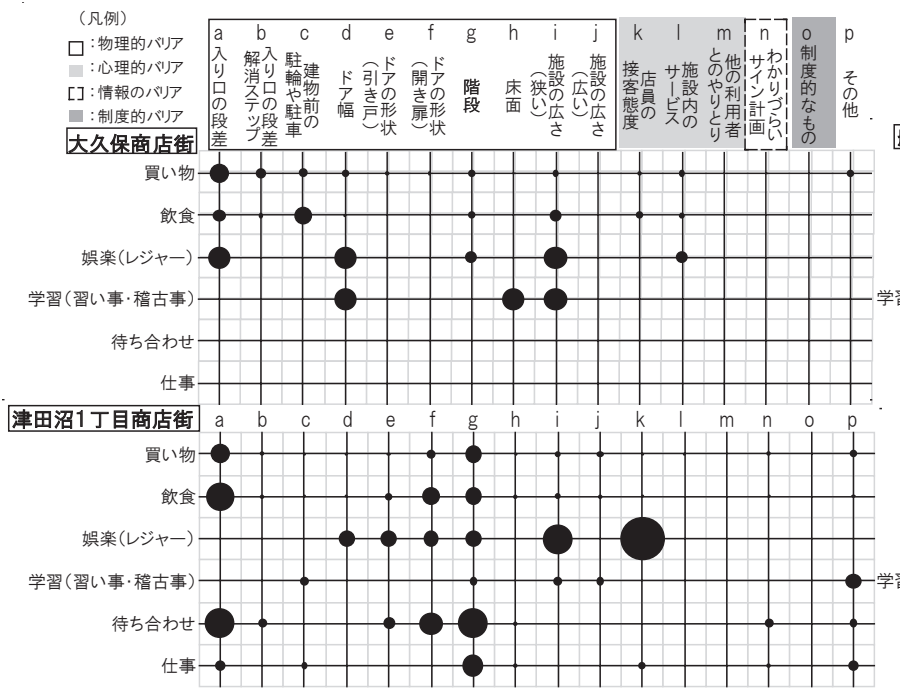

さ(狭い)」についての回答がみられ、全ての商店街で物理的バリア を意識する傾向がある。

2）飲食

「飲食」に関して、大久保商店街は $24.2 \%$ 、津田沼 1 丁目商店街 は $60.7 \%$ 、船橋駅前商店街は $29.4 \%$ 、銀座通りは $24.7 \%$ が意識す るバリアが有ると回答した。具体的には大久保商店街を除く 3 つの 商店街で「入り口の段差」が最も高い割合を占めており、次いで、 津田沼 1 丁目商店街及び銀座通りでは「階段」が高い割合を占めて いる。一方で、大久保商店街では「建物前の駐輪や駐車」が最も高 い割合を占めており、「買い物」目的の利用者が意識するバリアと異 なる傾向がみられる。加えて、津田沼 1 丁目商店街では「ドアの形 状（開き扉）」が他の商店街と比較して高い割合を占めている。

3 ) 娛楽 (レジャー)

「娛楽（レジャー）」に関して、大久保商店街は $42.9 \%$ 、津田沼 1 丁目商店街は $23.1 \%$ 、船橋駅前商店街は $11.8 \%$ 、銀座通りは $30.8 \%$ が意識するバリアが有ると回答した。具体的には津田沼 1 丁目商店 街の「店員の接客態度」が他の商店街と比較して最も高い割合を占 めており、「入り口の段差」に回答が集中する「買い物」等の利用目 的と異なり、心理的バリアに関する回答もみられる。

4) 学習 (習い事・稽古事)

「学習 (習い事・稽古事)」に関して、大久保商店街は $20.0 \%$ 、 津田沼 1 丁目商店街は $27.3 \%$ 、船橋駅前商店街は $15.4 \%$ が意識する バリアが有ると回答した。大久保商店街及び船橋駅前商店街では入 り口のドアに関連するバリアを意識する傾向がみられる。

5 ) 待ち合わせ

「待ち合わせ」に関して、津田沼 1 丁目商店街は $52.2 \%$ 、船橋駅 前商店街は $18.5 \%$ 、銀座通りは $29.2 \%$ が意識するバリアが有るとい う回答を得た。具体的には、「入り口の段差」に関して銀座通り及び 津田沼 1 丁目商店街での回答が集中する傾向がみられ、船橋駅前商 店街では「階段」及び「施設の広さ（狭い）」に回答がみられた。

6 ) 仕事

「仕事」に関して、津田沼 1 丁目商店街は $51.7 \%$ 、船橋駅前商店 街は $19.5 \%$ 、銀座通りは $30.8 \%$ が意識するバリアが有ると回答し、

「待ち合わせ」目的と同様に大久保商店街では意識するバリアは無 いという回答を得た。具体的には、「待ち合わせ」目的の結果とは異 なり、船橋駅前商店街の「入り口の段差」が他の商店街と比較して 高い割合を占める傾向がみられる。

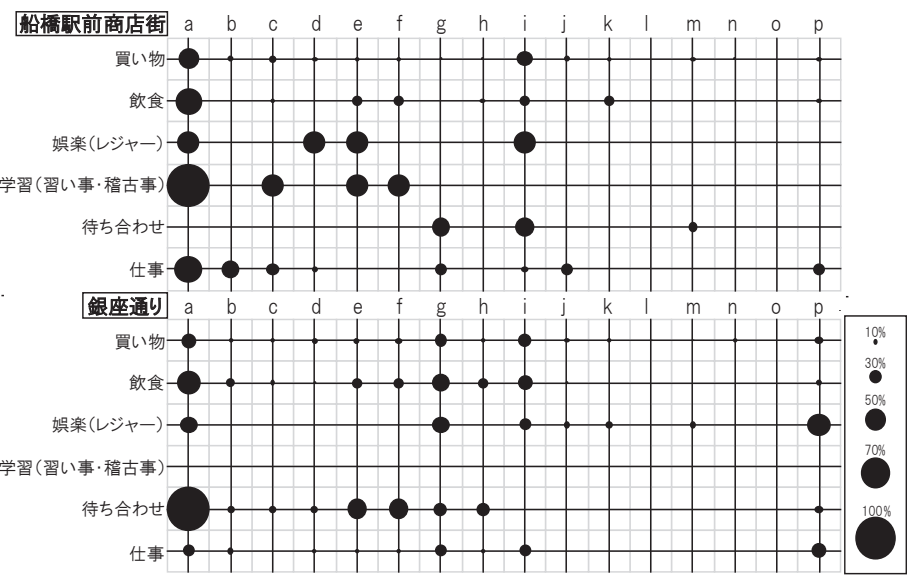

図 7 施設（建物空間）利用において意識するバリア（利用目的別） 
5.3.3 商店街 (外部空間) 利用において意識するバリア (利用目的別) 注9) (図8)

利用者が商店街（外部空間）で意識するバリアに関して利用目的 別にみると、大久保商店街では「娛楽（レジャー)」目的について全 ての利用者が意識するバリアが有ると回答し、津田沼 1 丁目商店街 では全ての利用目的で約 7 割から約 9 割が意識するバリアが有ると 回答しているが、「娛楽 (レジャー)」目的利用者は約 4 割の回答に 留まっている。船橋駅前商店街では「仕事」目的利用者の回答が高 い割合を占め、津田沼 1 丁目商店街同様「娛楽 (レジャー)」目的利 用者は約 3 割に留まっている。銀座通りでは全ての利用目的におい て約 3 割の利用者が意識するバリアが有ると回答し、利用目的別に 大きな差はなかった。具体的に、各商店街利用者の意識するバリア について、回答数が少なかった「理・美容」を除く全ての利用目的 項目別に整理する。

1) 買い物

利用目的として最も回答の多い「買い物」に関して、大久保商店 街は $82.8 \%$ 、津田沼 1 丁目商店街は $80.1 \%$ 、船橋駅前商店街は $61.0 \%$ 、銀座通りは $36.7 \%$ が意識するバリアが有ると回答した。全 商店街で物理的バリアに関して意識する傾向があり、大久保商店街 では「歩道の障害物」等の静的な物理的バリアより「走行中の自転 車等」の動的な物理的バリアに対して意識する傾向がみられる。

2 ）飲食

「飲食」に関して、大久保商店街は $81.1 \%$ 、津田沼 1 丁目商店街 は $88.5 \%$ 、船橋駅前商店街は $50.1 \%$ 、銀座通りは $32.5 \%$ が意識す るバリアが有ると回答した。特に、津田沼 1 丁目商店街では動的な 物理的バリアと「施設の所在」といった情報のバリアや「まちの景 観・騒音」といった心理的バリアを、銀座通りでは歩道に関する物 理的バリアを意識する傾向がみられる。

3 ) 娛楽（レジャー）

「娛楽（レジャー)」に関して、大久保商店街は $100 \%$ 、津田沼 1 丁目商店街は $38.5 \%$ 、船橋駅前商店街は $29.4 \%$ 、銀座通りは $26.9 \%$ が意識するバリアが有ると回答した。津田沼 1 丁目商店街では物理
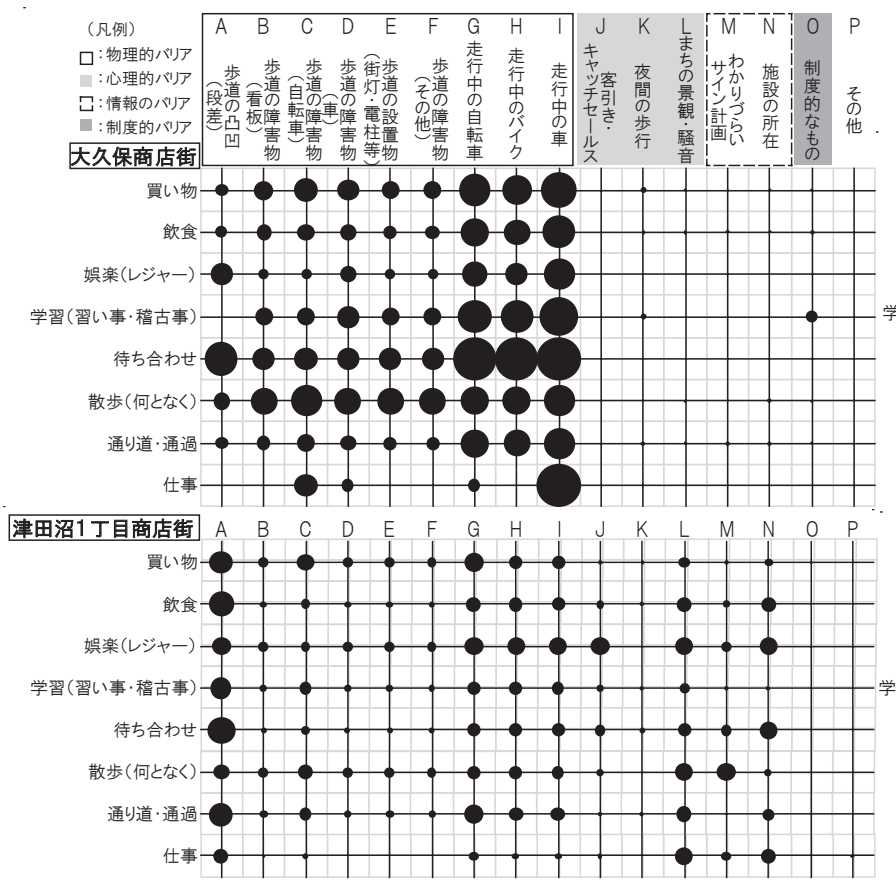

図 8 商店街 (外部空間) 利用において意識するバリア (利用目的別)
的バリアに加えて「施設の所在」といった情報のバリアや「客引き ・ キャッチセールス」や「まちの景観・騒音」といった心理的バリア について意識する傾向があり、船橋駅前商店街では「歩道の障害物」 等の静的な物理的バリアに加えて「わかりづらいサイン計画」とい った情報のバリアを意識する傾向がみられ、この 2 つの商店街では 共通して情報のバリアを意識する傾向がみられる。

4 ) 学習 (習い事・稽古事)

「学習 (習い事・稽古事)」に関して、大久保商店街は $80.0 \%$ 、 津田沼 1 丁目商店街は $68.2 \%$ 、船橋駅前商店街は $46.2 \%$ が意識する バリアが有ると回答した。大久保商店街では、「歩道の凸凹（段差）」 の回答が無く、他の利用目的とは差異性がみられる。

\section{5 ) 待ち合わせ}

「待ち合わせ」に関して、大久保商店街は $80.0 \%$ 、津田沼 1 丁目 商店街は $78.3 \%$ 、船橋駅前商店街は $48.1 \%$ 、銀座通りは $20.8 \%$ が 意識するバリアが有ると回答した。全ての商店街で物理的バリアに 回答が集中しているが、津田沼 1 丁目商店街及び銀座通りでは情報 のバリアを意識する傾向もみられる。

6 ）散歩（何となく）

「散歩（何となく）」に関して、大久保商店街は $75.0 \%$ 、津田沼 1 丁目商店街は $78.9 \%$ 、船橋駅前商店街は $40.0 \%$ 、銀座通りは $32.0 \%$ が意識するバリアが有ると回答した。特に津田沼 1 丁目商店街では 情報のバリアや心理的バリアを意識する傾向がある。

7 ) 通り道・通過

「通り道・通過」に関して、大久保商店街は $80.0 \%$ 、津田沼 1 丁 目商店街は $80.0 \%$ 、船橋駅前商店街は $53.8 \%$ 、銀座通りは $66.7 \%$ が意識するバリアが有ると回答した。大久保商店街を除く 3 商店街 で「歩道の凸凹 (段差)」が他の項目に比心゙高い割合を占める。

8 ) 仕事

「仕事」に関して、大久保商店街は $80.0 \%$ 、津田沼 1 丁目商店街 は $75.9 \%$ 、船橋駅前商店街は $78.0 \%$ 、銀座通りは $36.5 \%$ が意識す るバリアが有ると回答した。特に、船橋駅前商店街では物理的バリ アを意識する傾向が強く、銀座通りでは「施設の所在」等の情報の バリアに関する回答もみられる。

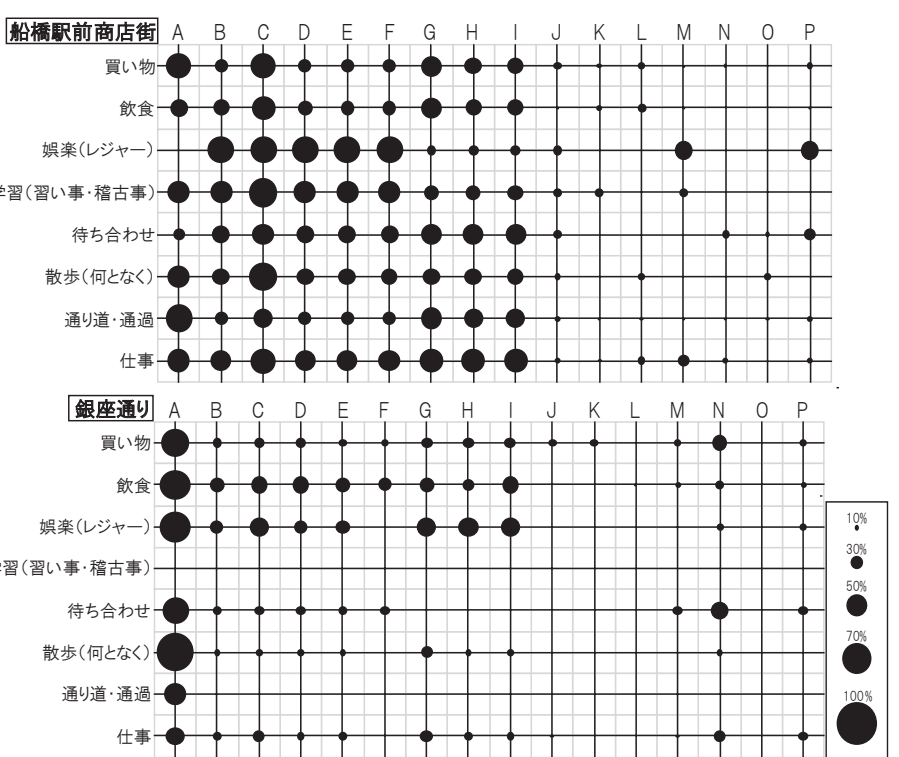




\section{6. まとめ}

本研究では施設（建物空間）並びに商店街（外部空間）利用の両 面で商店街の問題点や課題の整理並びに、4 つのバリアの種別分類 を通じて、利用者が意識する商店街別のバリアの特徴や傾向を明ら かし、以下の基礎的知見を得た。

1 ）利用者は施設（建物空間）及び商店街（外部空間）において、 全世代の男女共に利用の際に意識するバリアが有ると回答し、商店 街全体において利用しづらい（不都合や使いづらさを感じる）箇所 はハンディキャップや高齢層に限定されることではないことを裏付 けたと言えよう。また、今回得た調查結果から、利用者は施設（建 物空間）よりも商店街（外部空間）で意識するバリアが有ると回答 する傾向が強く、その割合は超広域型商店街である銀座通りが最も 低く、近隣型商店街である大久保商店街では最も高い（銀座通り： $35.4 \%<$ 船橋駅前商店街： $55.2 \%<$ 津田沼 1 丁目商店街 : $79.3 \%<$ 大久保商店街： $80.3 \%$ ）傾向がみられた。

2 ）施設（建物空間）において、全ての商店街で入り口の段差をバ リアとして意識する傾向が強く、入り口の段差解消ステップや建物 前の駐輪等、外部空間から内部空間に入るアクセシビリティを意識 する傾向がある。加えて、4つのバリア種別分類を行った結果、物 理的なバリアについて全世代の男女共に、ハンディキャップの有無 に関わらず、問題視する傾向が顕在している。特に、入り口の段差 に関して、箇所数、段差形態や高さに関わらず、利用者はバリアと して認識する傾向があり、改善が必要であることを裏付けたと言え よう。一方で、利用目的別に利用者が意識するバリアの傾向につい て各商店街で差異性がみられる。

3 ) 商店街（外部空間）において、4つのバリア種別分類を行った 結果、全ての商店街で全世代の男女共に歩道に関する物理的バリア を意識する傾向がみられる。特に、大久保商店街では走行中の自転 車等の動的な物理的バリアを意識し、津田沼 1 丁目商店街、船橋駅 前商店街、銀座通りでは歩道の凸凹（段差）や歩道の障害物といっ た静的な物理的バリアを意識する傾向がみられ、各商店街のメイン 通りの形態が一因であると考えられる。また、施設の所在といった 情報のバリアに関して超広域型商店街である銀座通りや地域型商店 街である津田沼 1 丁目商店街で、まちの景観・騒音といった心理的 バリアについては津田沼 1 丁目商店街で高い割合を占める傾向があ る。各利用目的別にみても、物理的バリアを意識する傾向が強いが、 近隣型商店街である大久保商店街において散歩や通過目的の利用者 は歩道の凸凹（段差）をあまり意識しない一方で、その他 3 つの商 店街では歩道の凸凹(段差)を意識する傾向が強いことが判明した。

4）1）～3）の調查・分析結果をふまえ、各商店街で取り組むこ とが可能な方策について、以下に示す。

(1)大久保商店街 : 入り口の段差は歩道の有効幅を確保した適正な段 差解消ステップによる改善が望ましく、建物前の駐輪・駐車に関し て、施設単位でのマナー対策や歩道の障害物（自転車）等の改善と 連携した適切な駐輪・駐車スペース対策が必要であると言えよう。 (2)津田沼 1 丁目商店街 : 入り口の段差や建物前の駐輪・駐車、歩道 の障害物に関して、大久保商店街同様の方策が望ましく、まちの景 観や騒音については商店会等の運営側による検討が必要と考える。 (3)船橋駅前商店街：入り口の段差解消において、更に狭小な歩道空 間を生み出す原因となる段差解消ステップによる改善は望ましくな
く、現在の入り口とは異なる適正なアプローチ空間が必要であると 共に、歩道沿いの駐輪スペースについても改善が望ましい。

(4)銀座通り：景観等のデザインルールがある銀座通りでは、段差解 消ステップによる入り口の段差解消は望ましくなく、EV に至るまで の階段解消も困難である為、船橋駅前商店街同様、現在の入り口と は異なる適正なアプローチ空間を設けることが望ましい。

今後は、商店街を構成している運営者（施設経営者）が意識する 商店街の問題点及び課題について検討すると共に、商店街における 問題点・課題の解決手法の検討に向けた更なる展開を課題と寸る。

\section{謝辞}

本研究におきまして、各商店街の商店会会長をはじめとして、聞 き取り調査にご協力いただきました方々、本調査・研究に関係する 様々な方々に多大なるご協力をいただきました。ここに記して謝意 を表します。

注

注 1 ）商店街で営業する販売、飲食、業務、娛楽、教育、病院等を総称して 「施設」と表記する。

注 2 ）「バリア」とは、一般的に障がい者等にとって障壁となる事柄を指し、 「障害者白書」において 4 つのバリア（物理的バリア、意識のバリア、 制度的バリア、文化・情報のバリア）が定義されている。本研究では、 障がい者等に限定せず、商店街利用者が安心・安全の妨げ又は不都合 や使いら゙らさを感じる種々の問題点や課題を「バリア」と定義する。

注 3 ) 全ての調查は杖使用身体障がい者 1 名、健常者 3 名（日本大学生産工 学部大学院生等) で実施した。

注 4 ）事前に用意したバリアの項目は、障害者白書の中で定義されている 4 つのバリア (物理的バリア、意識のバリア、制度的バリア、文化・情 報のバリア）を基に、目視・実測調查から得た結果より作成した。

注 5 ) 聞き取り調查の際、バリアの項目は、4 つのバリアに分類されていな い項目表を用いて実施した。

注 6 ） ゼンリン住宅地図、インターネットでの事前調査及び目視調查より、 各商店街で運営する施設の業種について日本建築学会・建築資料集成一 建築分類法を基に分類している。各ビルに対して複数階に渡りテナン 卜を展開している施設に関しては 1 件としてカウントしている。(例： $\mathrm{A}$ ビルの 1 階〜 5 階は同じメーカーの衣類販売店の場合は「販売施設・ 店舗」 1 件としてカウント) また、百貨店や大型量販店等に関しては、 「販売施設・店舗」に分類している。

注 7 ）国土交通省道路局が公表している「平成 17 年度道路交通センサス一般 交通量調査」において、平日 12 時間交通量の歩行者数は大久保商店街 (長沼船橋線) で 593 人、津田沼 1 丁目商店街（津田沼停車場前原線） で 17,085 人、船橋駅前商店街（船橋停車場線）で 40,625 人、銀座通 り (中央通り) で 24,870 人である。加えて、平日 12 時間交通量の自 転車数は大久保商店街で 619 台、津田沼 1 丁目商店街で 1,000 台、船 橋駅前商店街で 1,996 台、銀座通りで 1,198 台である。

注 8 ) 施設の営業年数並びに施設利用者年齢層について、運営者（施設経営 者）に対するアンケート調查を実施している。尚、各商店街の回答率 は大久保商店街： $87.0 \%$ 、津田沼 1 丁目商店街 : $56.4 \%$ 、船橋駅前商 店街 : $72.0 \%$ 、銀座通り：58.3\%である。

注 9 ) 利用者に対する聞き取り調査では、商店街に来た主要の目的を 2 つま で回答してもらい、施設（建物空間）並びに商店街（外部空間）にお いて意識するバリアの回答を得ている。従って、調查対象者の各利用 目的に対して意識するバリアを捉えている。

\section{参考文献}

1) 川内美彦：ユニバーサル・デザインの仕組みをつくる スパイラルアッ プを実現するために、学芸出版社、2007.8

2 ) 熊谷良雄 : 消費者の購買地選択行動よりみた商店街の配置に関する研究 （その 1）、日本建築学会論文報告集、第 191 号、pp. 83〜 88、1972.1

3 ) 熊谷良雄 : 消費者の購買地選択行動よりみた商店街の配置に関する研究 （その 2 ）、日本建築学会論文報告集、第 192 号、pp. 81〜 86、1972.2 
4 ）佐々木嘉彦、近江隆、山田博人、菅井壮文 : 購買地選択行動からみた商 店街の変動に関する研究 その 1 消費者購買行動のモデル化、日本建 築学会論文報告集、第 291 号、pp. 71 77、1980. 5

5 ）佐々木嘉彦、近江隆、山田博人、菅井壮文：購買地選択行動からみた商 店街の変動に関する研究 その 2 購買行動変化のモデル・シミュレー 卜、日本建築学会論文報告集、第 303 号、pp. 111 117、1981.5

6 ) 森田孝夫：京都の都心商店街活性化計画のための顧客分析、日本建築学 会計画系論文報告集、第 437 号、pp. 27〜36、1992. 7

7 ) 森田孝夫：京都の都心商店街活性化計画のための通行量分析、日本建築 学会計画系論文報告集、第 451 号、pp. 115～125、1993.9

8 ）大島秀明、天野克也、谷口汎邦：商店街来街者の座りスペース利用に関 する研究一巣鴨地蔵通り商店街の場合一、日本建築学会計画系論文集、 第 610 号、pp. 41 46、2006. 12

9 ）金俊豪、三橋伸夫、藤本信義 : 商店街における休鄎スペースの空間構成 と利用評価に関する研究、日本建築学会計画系論文集、第 615 号、pp. 75 $\sim 82 、 2007.5$

10）竹内昌史、吉田环美、兼田敏之：回遊行動からみた商店街複合地区の動 態分析一 2008 年名古屋市大須地区調查の結果を中心として一、日本建築 学会計画系論文集、第 660 号、pp. 361 368、2011.2

11）平田圭子、浅沼則行、菅原辰幸 : 祭事における商店街来街者の座り空間 整備に関する研究、日本建築学会計画系論文集、第 663 号、pp. 895 902、 2011. 5

12）大坂谷吉行、川端智浩：ハートビル法認定建築物の分析とバリアフリー の商店街づくり、日本建築学会技術報告集 第 5 号、pp. 242 247、 1997. 12

13）坂野宏行：高齢者の生活空間としての小売商店街に関する研究、日本建 築学会大会学術講演梗概集、F、pp. 345～346、1993.9

14）大屋裕一、園田眞理子、佐藤克志：商店及び商店街における福祉的環境 整備のあり方とその経済効果に関する研究 三鷹駅前商店街の周辺住民 に対するアンケート結果からの考察、日本建築学会大会学術講演梗概集、 E-2、pp. 427〜478、2001.9

15）鴨崎義人、片岡正喜、鈴木義弘、中武啓至、三宮基裕、石津史郎：別府 市亀川商店街の車い寸利用のための店舗改造の取り組み 別府市太陽の 家に隣接する亀川商店街の車い寸生活者との共存化に関する研究、日本 建築学会大会学術講演梗概集、E-2、pp. 441 442、2000.9

16）石津史郎、片岡正喜、鈴木義弘、中武啓至、三宫基裕、鴨崎義人：別府 市亀川商店街における店舗の現状と問題点 別府市太陽の家に隣接する 亀川商店街の車いす生活者との共存化に関する研究、日本建築学会大会 学術講演梗概集、E-2、pp. 443〜 444、2000.9

17）湧井志野、園田眞理子：商店及び商店街の福祉的環境整備のあり方に関 寸る研究一高齢者、車い寸使用者の買い物行動から見た商店及び商店街 の問題点一、日本建築学会大会学術講演梗概集、F-1、pp. 413 414、2001.9

18）大野拓也、井上芳恵：兵庫県山崎町における商店街の整備課題に関する 高齢者と商店主の意識比較一高齢社会に対応した地域施設の整備手法に 関する研究一、日本建築学会大会学術講演梗概集、E-1、pp. 481〜 482、 2001. 9
19）竹内友哉、藤岡泰寬、大原一興：長期利用者を通してみた身近な商店街 の多面的評価に関する研究一商学協働事業から地域まちづくりへの発展 に関する研究 その 5 -、日本建築学会大会学術講演梗概集、F-1、pp. 1083 $\sim 1084 、 2007.8$

20）中小企業庁委託事業：平成 21 年度商店街実態調査報告書、2010.3

21）内閣府: 平成 23 年版 障害者白書、2011 年

22）井手郁子、小形涼子：KIRACO Vol. 45、有限会社きらこ編集室、2004. 1

23）井手郁子、小形涼子：KIRACO Vol. 46、有限会社きらこ編集室、2004.3

24）大久保商店街協同組合：大久保商店街ガイドマップ

25）津田沼一丁目商店会：ぶらり津田沼お散歩 MAP

26）銀座街づくり会議・銀座デザイン協議会 : 銀座デザインルール 第二版、 全銀座会・一般社団法人 銀座通連合会、2011. 12

\section{既発表論文}

i ）野田りさ、川岸梅和、北野幸樹：市街地空間におけるバリアの実態に関 する研究一習志野市大久保地区をケーススタディとして一、2009 年度日 本建築学会関東支部研究報告集 II 、No. 80、pp. 325 328、2010.3

ii ）野田りさ、川岸梅和、北野幸樹 : 市街地空間におけるバリアの実態に関 する研究一施設のアクセスに関するバリアについて（習志野市大久保地 区をケーススタディとして)－、日本建築学会大会学術講演梗概集、E-1、 pp. 681〜682、2010.9

iii）野田りさ、川岸梅和、北野幸樹：市街地空間におけるバリアの実態に関 する研究（その 2$)$ 一習志野市津田沼 1 丁目地区をケーススタディとし て一、2010 年度日本建築学会関東支部審查付き研究報告集 6、pp. 89〜92、 2011.8

iv）野田りさ、川岸梅和、北野幸樹：市街地空間におけるノーマライゼーシ ヨンに向けた環境づくりに関する研究（近隣型商店街と地域型商店街の 比較からみた考察) 、日本建築学会大会学術講演梗概集、E-1、pp. 701 〜 702、2011. 8

v ）野田りさ、川岸梅和、北野幸樹：市街地空間におけるバリアの実態に関 する研究（その 3 ）－船橋駅前商店街をケーススタディとして一、2011 年度日本建築学会関東支部研究報告集 II N No. 82、pp. 285 288、2012.3

vi）野田りさ、川岸梅和、北野幸樹：商店街におけるバリアの実態に関する 研究（船橋駅前商店街の利用者・運営者の比較による考察）、日本建築 学会大会学術講演梗概集、E-1、pp. 959 960、2012.9

vii) Risa Noda and Umekazu Kawagishi: Study on the Welfare Environment in Shopping Streets regarding the Properties of Awareness Barriers and Spatial Barriers Perceived by Users and Operators in Different Shopping Streets, THE 9TH INTERNATIONAL SYMPOSIUM ON ARCHITECTURAL INTERCHANGES IN ASIA TECHNOLOGICAL ADVANCEMENT IN ARCHITECTHURE, October 22 25,2012, KDJ CONVENTION CENTER, GWANGJU, KOREA

（2012年12月10日原稿受理，2013年 5 月13日採用決定） 